\title{
Talk Shows in Pakistan TV Culture: Engaging Women as Cultural Citizens
}

\author{
Munira Cheema ${ }^{1 *}$
}

Published: March 19, 2018

\begin{abstract}
Gendered content that travels through popular TV in Pakistan highlights gender-based crimes and allows women access to the mediated public sphere. This is an unprecedented form of access in a society that defines public/private through Shariah. The boundaries between the two spheres have thus far been immutable. Recent changes in the media landscape have made these boundaries porous. Drawing on theoretical debates on popular culture, cultural citizenship and counter public sphere, the study argues that these popular cultural spaces can be read in terms of an emerging feminist public sphere where women can engage as members of the public and as cultural citizens. To determine engagement patterns of young viewers, focus groups turned out to be effective method. In the sample of university students, there were 42 participants in 10 groups with 4 to 6 members in each group. The study finds that gendered content allows women to act in pro-civic ways. Their engagement with this content allows viewers to revisit their intersecting identities as Muslims, women and Pakistanis.
\end{abstract}

Keywords: cultural citizenship, shariah, Pakistan, talk show, women audiences

\section{INTRODUCTION}

In the last decade, the Pakistani media landscape has significantly changed. Up until 2002, Pakistani audiences were largely (if not entirely) relying on state TV (PTV) for news and entertainment (c.f. Ali, 1986). In 2002, the Pakistani government liberalised the media by issuing licences to private broadcasters. These broadcasters not only introduced new genres (interactive TV) but also started experimenting with topics that were not welcomed on state TV (controversial topics such as religion and gender). I identify that the new wave of gendered content highlights controversial issues such as honour killings, rape, child abuse, rights of transgender, the violation of women's divorce rights, balala, marriage with the Holy Quran, stoning, adultery, prostitution, domestic violence and the subjugation of women in the extended family system (c.f. Cheema, 2016) ${ }^{1}$. Following Felski (1989), Fraser (1990), Benhabib (1992), McLaughlin (1993) and Landes (1998), I identify this content in television as an emerging feminist public sphere. As a feminist media researcher, I read popular culture as an alternative or counter public sphere. I argue that talk shows should be read in terms of counter public spheres that have started to be heard in the mainstream public sphere on gender issues (child abuse, rights of transpersons, rape, honour killings). Moreover, it is not only on the production side (in studio), but in viewing contexts that one can locate counter publics/public sphering. I will argue viewers' reflection on gendered content can be read in terms of cultural citizenship. Drawing on viewers' discourse, I argue that gendered content can be used effectively for feminist agendas. ${ }^{2}$

\footnotetext{
${ }^{1}$ The term 'halala' is when a man has irrevocably divorced his wife, and they (or some people) intentionally plan and arrange for another person to temporarily marry the (divorced) wife, so that the wife can again become legal again for the first husband. This intentional plotting and planning for arranging the temporary marriage of the divorced wife with another person to intentionally circumvent the Laws of Allah and make her legal for her first husband is what is known as 'halala'. This definition is cited on Islamhelpline.net, Available at

http://www.islamhelpline.net/node/4722 (accessed 20 September 2014).

2 This article emerges from a wider project that looks at the production and reception of gender-based content in Pakistani TV cultures (c.f. Cheema, 2015).
} 
The post-liberalisation period is notably defined by a 'change' in content. Although change can be seen across television programming, I am mainly interested in gendered content. ${ }^{3}$ There are two attributes to this change: firstly, it breaks the silence on gender-based issues in Pakistani society and secondly, it gives women improved access to the mediated public sphere.

While acknowledging change in gendered content, this study aims to share findings of how young women, specifically university students, engage with interactive genres in Pakistani TV culture that highlight new forms of gendered content. By interactive genres, I refer to shows that allow women access to the mediated public sphere through letter-writing, in person, phone, email and social media. Categories in interactive TV can include religionbased talk shows, social issues-based talk shows, breakfast and crime shows. These are panel-based shows where host takes questions from the public (mostly women) that are discussed among the panel of experts. Experts include, clergymen, social activists, lawyers and celebrities. With slight variations in format, all categories highlight gender-based issues. This article will demonstrate how viewers' engagement with 3 categories of talk shows allows them to reflect on gendered realities in Pakistani society.

To determine the engagement patterns of young adult viewers, focus groups turned out to be an effective method. In the sample of university students, there were 42 participants in 10 groups with 4 to 6 members in each. Given that an ethnographic approach towards reading audiences emphasises the importance of the context and insists that being an audience (or "doing audiencing" or "consuming technologies") should not be abstracted from its social context' (Kitzinger, 2004: 178), I conducted all focus groups in the Arts Lobby, a popular social space at Karachi University. Students use this space for socialising and usually sit with friends in groups of 4 to 10. Groups who watched these shows on a regular basis volunteered to become part of these discussions. Members of the groups knew each other well, in most cases they belonged to the same department. Using a template for semistructured interviews, most discussions started off with recalling the 'glorious' days of PTV and how content has changed after privatisation. Prompts were used to discuss gendered content across genres. Students mostly discussed among themselves and I only intervened when participants were either talking simultaneously or went off-topic. ${ }^{4}$

The data used in this study emerges from different groups that have reflected on gendered content in interactive TV. I traced viewers' engagement with gendered content across 6 shows. These are: Alim aur Alam (Scholar and the Global Society), Hawa Ki Baiti (Daughter of Eve), Geo Hina Kay Sath (Live with Hina), Utho Jago Pakistan (Wake Up Pakistan), Subb Saveray Maya Kay Sath (Early Morning with Maya), and Good Morning Pakistan. In addition, two case studies from crime shows, Shabbir Toh Dekhay Ga (Shabbir Will Watch) and Jurm Bolta Hae (Crime Speaks) were selected that fall into the category of narrative form as well as interactive genres.

\section{Access to the Mediated Public Sphere:}

The essence of this study lies in exploring women's access to the mediated public sphere in a society that is becoming increasingly conservative. Women's access to the public sphere is heavily influenced by hegemonic Islamic discourse as the state religion, which depicts 'home' as women's natural sphere of activity, and their participation in the public sphere as regulated by male guardians (mahram). I do not mean to generalise this scenario by stating that all women have limited access to the public sphere, or that there are hardly any women who are free to struggle against the religious and cultural practices that bar women's access to the public sphere (c.f. Cheema, 2018). Of course, it is clear that Pakistani women do not form a homogenous whole with the same aspirations for identical social behaviour, and are intersectional subjects.

Significant for this project is how interactive genres give women access to the mediated public sphere, with gendered content directly challenging the public/private distinction of Pakistani society laid under Shariah. This distinction is defined by the contemporary Muslim scholars inclined toward the Hanafi school of thought. For a long time, scholars (such as Abul Ala Maududi, Israr Ahmed and Amin Ahsan Islahi) who campaigned for political Islam opposed women's participation not only in politics, but also, in any other activity 'outside the home'. In justifying his stance on women's sphere of activity, Maududi (2010) relies on the hadith that 'the woman is not allowed to go on a journey except in company of a mahram' (a male member of the family with whom sexual relationship is forbidden) (2010: 148). In the light of the hadith from Abu Da'ud (third of the canonical hadith

\footnotetext{
${ }^{3}$ I have chosen to call it 'gendered content' because themes mainly address women issues but also touch other gender-based issues such as homosexuality and rights of transgender people.

${ }^{4}$ In the first stage of transcribing, most of the data was transcribed in the form of notes taken during recording and conducting the interviews and the focus groups. The second stage of transcribing was the stage of 'data reduction' (McLellan, MacQueen, Neidig, 2003: 66). The data reduced was that which did not fall into the scope of this study or where participants had completely diverted from the topic, but I did not discard the written notes about visual cues, body language and gestures that were equally important to reinforce any ideas about identity construction and social meanings. In the third stage of transcribing the data, the thorough examination of the fieldwork was undertaken to identify the common themes in discussions.
} 
collections), Maududi further notes that 'the most appropriate place for her according to the Islamic law is her home' (148). Amidst rising conservatism in Pakistan, this belief is garnering appeal across different classes in the society. While Muslim scholars with a more liberal outlook (Wudud (1999), Asma Barlas (2002), Asghar Ali Engineer (1997) and Javed Ahmed Ghamidi (2010)) have attempted to rearticulate this distinction and the role/place of women in society, they struggle to get 'air time' on screen because broadcasters are fearful of giving them space (c.f. Cheema, 2016, 2018).

This study notes that interactive shows, however, give women access to media without displacing them from home. This is a unique and unprecedented form of access that transcends physical boundaries laid by Shariah. Interestingly, it does not essentially need accompanying a mabram to access the public sphere. In this sense, the liberalisation of media has opened up many areas for debate. I am fundamentally interested in how the public/private distinction has become negotiable by giving access to women (without mahram) to the mediated public sphere.

\section{THEORETICAL PREMISE: POPULAR CULTURE AND CULTURAL CITIZENSHIP}

Gendered content travels across different genres in popular culture and offers spaces for the intersection of the social, private, public and the political. Popular culture plays an important role in nurturing an environment in which dominant ideologies can be challenged. More importantly, it can also allow its consumers to perform like responsible citizens. In other words, the production and consumption of popular content can be organized around civic concerns. For instance, the issue of gendered crime and state law is a common theme in popular genres in Pakistani TV culture. Such content enables audiences to reflect on these issues and react as concerned citizens. This practice of performing as citizens in relation to cultural products is referred to as cultural citizenship.

Scholars define cultural citizenship as a concept that initiates and celebrates symbolic representation and discussion on otherness and tolerance. (c.f. Isin and Wood, 1999; Pakulski, 1997). Stevenson argues that 'questions of cultural citizenship therefore seek to rework images, assumptions and representations that are seen to be exclusive as well as marginalizing' (2001: 4). I argue that gendered content facilitates the access of 'left out' members of society to the public sphere in two ways. Firstly, by giving a platform to victims of gender-based crimes to narrate their stories, and secondly, by giving access to female viewers (to perform as cultural citizens) who may otherwise not participate in the public sphere. Hermes (1998), Dahlgren (1995) and Wieten (1998) directly link the concept of cultural citizenship to popular culture. Hermes (2005: 10) defines cultural citizenship as 'the process of bonding and community building, and reflection on that bonding, that is implied in partaking of the text-related practices of reading, consuming, celebrating, and criticizing offered in the realm of (popular) culture'. In case of this study, I argue that such popular culture invites women across class and age to reflect on the public/private distinction in Pakistani society (and thus on a defining aspect of women's role in society).

In academic literature, there is a tendency towards belittling the popular genres that offer sites for practising cultural citizenship. I argue, as researchers looking for possibilities of public sphering on gendered issues, our focus should turn towards locating spaces where gendered publics are invested. In most cases, gender-based issues are featured in serialized dramas and interactive TV. Audiences who behave as publics in the symbolic and imagined spaces of such programmes, may use these spaces for personal reasons as well as for the pro-social reasons.

I choose to use follow Dahlgren (2009), Hartley (1996), Hermes and Muller (2010) and Klein (2013), Lunt and Stenner (2005), McGuigan (2005) in tracing Habermasian public spheres within popular culture. While exploring how popular culture addresses issues of immigration and disability Klein (2013) argues that entertainment driven genres 'serve the goals of a public sphere' by providing additional material for generating discussion (Klein, 2013: 53). Sanli (2011) also stresses the importance of women-oriented talk shows (in a Turkish context) as a space to revisit the honour code. Taking it forward, I argue, in Muslim societies that nurture a culture of silence on gendered issues, popular culture offers the opportunity to initiate discussions on issues that matter to a large population of society.

Specifically, in Muslim societies that define public/private distinction through religion, boundaries between the public and the private have thus far been immutable. In many households that follow Shariah, women are neither allowed to step out of their homes without mahram, nor are they allowed to interact with issues of socio-political nature (which makes it an immutable aspect of life). I stress that popular culture plays a crucial role in negotiating that boundary. Hermes (2005) also identifies this potential by calling popular culture truly democratic and inclusive. The element of interactivity and an extraordinary interest in cultural products can produce newer identities and can also challenge existing understandings on rights of people. More importantly, entertainment provokes a kind of engagement with the public that 'lacks the cultural capital or competence to engage with democratic practice at a more political and abstract level' (Hermes, 1998: 160). In case of my project, I explore how women who may otherwise not engage in official political discourse on gender rights get the opportunity through such popular culture to voice their opinion. The entertaining aspect of popular culture bestows it with an unusual privilege 
(especially in conservative contexts) to challenge official narratives on citizenship and rights. Similarly, the rhetoric on talk shows may appear emotional, but it renders unique occasions to address issues that have thus far been excluded from the mainstream public sphere (c.f. Lunt and Stenner 2005 and Lunt and Pantti, 2009). At the same time, I stress that our understanding of the 'reflective spaces of the public sphere' should be more open and inclusive toward issues that prioritise emotions over reason. This does not in any way downplay the importance of the issue under consideration, or make it in any way less political.

Following Fraser (1990), Benhabib (1992), McLaughlin (1993) and Landes (1998), I read interactive TV as an emerging feminist public sphere. Thematically and methodologically, this study is also informed by other feminist media studies and formative research by Tania Modleski (1982), Ien Ang (1985), Hobson (1982) and Andrea Press (1991). While looking at soap operas, Modleski (1982) notes that soaps do highlight social issues such as rape, but popular feminine texts do not question women's obsession with 'the primacy of male-female relationships' (113). Hobson (1994) discusses soap opera with a group of six women and argues that viewers are not passive (1994: 166). She notes how viewing television and soap operas goes beyond the moment of reception: '[i]t indicates that a further stage of communication takes place when they talk about television programs and often the relating of those programs to the everyday life of the viewers' (167). Press (1991) reads how women of different economic backgrounds read the content of soaps in the US television culture. Most crucially, she suggests that how her research respondents 'interact with television culturally is more a function of their social class membership than their membership in a particular gender group' (177). This article also examines how audiences relate content to their everyday life and subjectivities.

In regional literature, the study has overlaps with Suleman (1999), Kothari (2005), Talib and Idrees (2012), Hashmi (2012) and Naqvi (2011). While analysing the Late Night Show (aired on private TV), Hashmi (2012) notes how content pushes the boundaries of mediated discourse on sexuality and gender. Suleman (1999), looks at drama serials as a site for challenging dominant ideologies. Likewise, Kothari's (2005) also studies drama serial as a crucial genre that is targeted towards women as audiences. She notes that dramas emphasise on 'home' as an essential sphere for Pakistani women.

Methodologically, my work is closer to both Mankekar's (1999) and Butcher (2003) who use interviews and focus groups to understand audiences' engagement with TV content. Mankekar (1999) studies Doordarshan's role in the portrayal and reconstruction of gendered realities during the 1980s and 1990s, combining interviews and observation. While she explores women's engagement with TV content on state television, this study focuses on private TV content. Butcher's study (2003) on transnational television and cultural change also uses focus groups across class to measure 'cultural change by looking at changing perceptions of Indianness, and the role of transnational television in the process of defining, creating and maintaining that identity'.

\section{RELIGION-BASED TALK SHOWS: CALLING WITHOUT CONSENT, PROTECTING IDENTITY}

For the religion-based talk shows, my two case studies were Alim Aur Alam 5 and Hawa ki Baiti.

Speaking firstly of Alim Aur Alam. This is a 30-minute shows that runs three times a week in which the host takes live calls from the viewers who either want to seek Shariah-based advice on issues of any nature or give voice to their opinion on a given topic. Though this show is open to all kinds of topics related to religion, female viewers (who seek advice on issues of personal nature) make a considerable number of the calls. In the studio, the host is accompanied by a panel of three male clerics from different Islamic sects who give advice on the issue at hand.

Going through the archives of the show, I identified recurrent issues for which women make live calls on these shows. I was not interested in quantifying the number of calls made by women but summarising the issues they brought to the mediated public sphere, focussing not only on the pattern of recurrence of (gender-related) dominant issues, but also on what is absent from the content. Most importantly, it was necessary to notice any deliberate or intentional silence on certain gender-based issues (transgender issues and homosexuality). This show offered spaces for producing/reinforcing socially constructed knowledge, and identifying such discourses laid the foundation of semi-structured interviews for the focus groups. I closely followed all the episodes of Alim Aur Alam (from 2010 to 2012), in particular I analysed 25 episodes of Alim Aur Alam (Scholar and Society) that were strictly

\footnotetext{
${ }^{5}$ Alim aur Alim is one of the most popular religion-based talk shows in Pakistan. The host of the show started his show under the name of Alim Online from the Geo TV. At the time of the fieldwork, he joined ARY Digital where he started his show (same format) under the title of Alim Aur Alam. In the year 2013, he joined back in the Geo TV as a Vice-President, but following the scandal of blasphemy in one of the other shows of the channel in April 2014, he has now joined Express TV as the President. He has also served as a Minister for Religious Affairs. Although he changes channels, his show continues under one title or the other.
} 
covering gender-based issues. From these episodes, I have extracted four major themes based on their recurrence in each episode watched. These include:

a) women calling in this show to know about their rights for a separate nuclear home (a home apart from in-laws);

b) women calling in to the live show to complain about their husbands' behaviour or that of in-laws;

c) women complaining about domestic violence faced at home, in most cases involving sexual harassment by the male members of the family;

d) families of the victims of gender-based crimes appearing on this show to give voice to their experience. ${ }^{6}$

In exactly, the same way, I analysed another religion-based talk show called Hawa Ki Baiti (Daughter of Eve) ${ }^{7}$. The format of Hawa ki Baiti varies from that of Alim aur Alam, in that it has a female-only panel for discussion, a two-member panel with a female cleric and a legal advisor. Such shows offer Shariah-compliant advice on issues; any issue that falls out of the scope of Shariah does not feature in these spaces. These types of shows deal with gender-based issues in a serious manner and I could not identify any implied intention to create a spectacle out of any victim's misery. What is significant here is that these shows provide a safe space for women to discuss issues of concern. It is important to note how young women (respondents in focus groups) make sense of this access to the mediated public sphere:

Rehma: Obviously, if a woman is suppressed at home (by in-laws), she cannot leave her house to approach anyone for help, then such shows offer the right sort of avenue for her. It is a limited sort of assistance but isn't bad at all, and it is safer for they don't have to reveal their identity. But women calling in such shows, should be careful about asking questions of very intimate nature (periods/sex) for they have a male panel, you know what I am trying to say.

Sobia: I don't think it is going to have any effect because their families wouldn't let them follow the advice they seek through calling. Maybe, they just call for their satisfaction, and for catharsis, but it wouldn't really change their lives in any way.

While Rehma acknowledges 'calling on shows' to be somewhat beneficial, Sobia does not see any good coming out it. While discussing this aspect, both refer to women living in joint household with in-laws. In Pakistan, the joint family system is prevalent in rural areas, cities and educated households, a household usually spanning three generations. Under Shariah, sons are responsible for providing maintenance to the parents but also a separate household for a wife. With rising costs of living, managing two households is not easy. Hence, in most cases, it is economically viable to stay in parental home and provide financial care to parents.

Most of the callers are daughters-in-law living in joint households who complain about their lack of privacy and how they are treated by mothers-in-law. Rehma and Sobia are referring to how daughters-in-law can use the show for voicing their concerns without revealing their identities, as the honour of the family resides in their concealment. Here, concealing their identities can also serve as a protective shield for women who choose not to reveal identity to protect their own safety at home. They are fully aware of the consequences of revealing their identities on television.

Most of the women I interviewed at Karachi University seemed confident, opinionated, yet religiously-inclined. A majority of these students wore hijab, and often quoted Islamic rulings on gender rights. Modest clothing can be read in terms of the practice that facilitates Muslims women's entry into public spaces (c.f. Ahmed, 2011). However, my intention is not to draw parallels between their dress and their religious inclination. With their presence in a public university, one can safely assume that these students do not associate themselves with the radical Islamic school of thought that prohibits women's participation in the public sphere at all. Yet, students referred to religion as their principal frame of reference for making day to day choices. Fabeha and Romaisa, students of General History Department, differed in their responses to 'live calling':

Fabeha: I don't think one should call, if you have an issue at home, it should be addressed within home. Besides, what are these women calling for, is it not to seek guidance through the Quran; do we not have the Book at home? Haven't we read it? And what if their families would come to know about their calling on such platforms, it can make the lives of these callers even worse.

\footnotetext{
${ }^{6}$ See for example: Alim aur Aalam, Episode 234 aired on ARY Digital uploaded by: sabakarachi00 (2012) Aamir Liaquat Part 2 Aalim aur Alam rape in Karachi 3 choti buchiya Episode 234 with Amir liaquar mp4. Available at

http:/ / www.youtube.com/watch?v=pCT1z5eXRYg (Accessed 4 July 2014)

${ }^{7}$ Lately, the channel has changed its title.
} 
Romaisa: I think it is empowering for women to call on Alim aur Alam for issues of personal nature. At least, one step forward.

It is in a way understood that viewers who are calling have not sought permission from their husbands/in-laws, and this lack of approval can land them into trouble within the home. Except for Romaisa, no one considered the experience/practice of calling as 'liberating/empowering', rather as an act of naivety. There is another dimension to this response. These young girls are all too familiar with cultural norms, and in a way they are implying that those who are calling to address their home-based issues, will be unable to stand up against their 'exploiters'.

While most of the viewers seem eager to watch this show, they do not imagine participating in such shows without the permission of male heads of family, which raises the question: how limited is the autonomy of these female viewers? In another related study on housewives' engagement with gendered content, I find that married women (focus group respondents) get permission not usually from their mahram (husband or father-in-law), but rather their mother-in-law who takes decisions on their behalf. This has nothing to do with Shariah, it is a cultural practice that empowers mothers-in-law and makes her sovereign in the private sphere (c.f. Cheema, 2018). In such instances, women are not essentially struggling against mahram (male members) of the household, but rather their main adversary is another woman who exercises patriarchal power on behalf of male guardians (mahram).

\section{BREAKFAST SHOWS: PUSHING THE BOUNDARIES OF GENDERED DISCOURSE}

In the case of breakfast shows, gender-based issues were highlighted once or twice a week. In Maya Khan's morning show, these cases were highlighted daily with specific campaigns run by this show to highlight issues of domestic politics. However, for other breakfast shows, I had to identify episodes where specific cases of abuse were highlighted. For this purpose, I analysed at least five episodes per show to understand their treatment of the gender-based issues. The shows in this category included: Subab Saveray Maya Kay Sath, Good Morning Pakistan and Utho Jago Pakistan.

In the case of Subh Saveray Maya Kay Sath, the approach towards the gender-based issues appears to be highly emotional and sensationalised, with everyone in the studio including the victim and the host seen in tears. This happens in the first 15 minutes of the shows where victims (usually rape victims or acid victims) or those accompanying the victims share their ordeals. The discussion takes a serious turn in the second half when law enforcement authorities, NGOs, legal advisors and the politicians are included. During these shows, live-callers (mostly women) call in to express their concern over such issues or express solidarity with victims. The discussion around the plight of women is wrapped up after assurances from the social activists, politicians and the host to follow up the case in future. However, what is worth noting is that the hosts of Subh Suveray Maya Kay Sath and Good Morning Pakistan are conservative in their approach towards such issues. The discussion often focuses on how perpetrators commit heinous crimes against the weaker gender (sinf-e-nazuk) who otherwise needs protection, against she who is naïve, and who should be cared for. The hosts do not talk about gender equality because of perceived editorial control over controversial subjects (c.f. Cheema, 2016, 2018).

In the case of Utho Jago Pakistan, the host is somewhat liberal in her approach towards gender-based issues. She is much more authoritative in tone. She inspires confidence in the victims of domestic violence, leading them to divorce. She has also taken up themes of 'gender identity crisis' and 'sexual ambivalence' in her show. Interestingly, in such episodes, she has usually avoided inviting religious scholars as discussants. The panellists on her shows include social activists, doctors, politicians and even celebrities. The discussions here tend to be less emotionallyladen, calmer and more analytical. There is clear evidence of using the show to make such issues socially and politically relevant. ${ }^{8}$ When I pursued this aspect with respondents, students of English Literature, they commented in this manner:

Sania: Speaking on just any issue on television is concerned, we [referring to her friends] don't think everything should really be discussed on a public medium. There should be some limits to this freedom. For instance, we should not be very open about issues of homosexuality. Our channels are giving extraordinary coverage to homosexuality and transgenders, that it will soon be a norm. Five years ago, it was unusual for us to know that someone is a homosexual or homosexuals are even part of this society, but now it is as if we have accepted them now.

Bushra: It is true that as students of literature we read anything that is otherwise restricted in our society, but there is a limit to what we can watch on a public medium (TV), see, we have some religious norms

\footnotetext{
${ }^{8}$ See for example: Topic 'gender identity crisis' on Utho Jago Pakistan. Utho Jago Pakistan published on April 30, 2012. Uploaded by pakmorning (2012) Utho Jago Pakistan $1^{\text {st }}$ May 2012 Part 3/7 High Quality. Available at:

https://www.youtube.com/watch?v=8IJwyHjEULc (Accessed 23 July 2014)
} 
as well. And religion gets involved in our life at all levels, so we can't really be open about everything, we simply can't do away with our religion. As far as acceptance is concerned, we can accept only if that falls under our limits; that is, to stress that we can accept a transsexual for his/her sexual orientation because it was given at birth by God but cannot accept any sexuality that is socially constructed (referring to homosexuals).

Rabeeya: Our limits should be clearly defined. If you look at the Westerners, it is no wonder that they have lost their limits and even their homes, because their kids are too informed about their rights, they just leave their homes and do whatever they want to. It is frightening to see how their family structure has collapsed.

Hina: But in a way, it is even good to know about certain issues and your rights as a citizen, because we can handle ourselves better in a crisis.

In Pakistan, religion is the central reference point for almost everything in life; from identity to daily activities, religion enforces silence on some issues while explicitly condemning certain acts. Homosexuality is depicted as an offence in Islam, hence on screen, homosexuality is represented as either an ailment or a sexual deviation. Mostly, such representations are used for comic relief or to reinforce stigma. There is a fear of normalizing homosexuality that directly challenges Shariah while there is also anxiety about losing conventional family structure. Both Shariah and family essentially define the social fabric of Pakistani society.

In this way, religion becomes involved with viewers' engagements with gendered content on TV in Pakistani culture, though it does not seem to affect their engagement with the literature they study in the same way. Bushra draws attention to how they perceive the nature of the medium, pointing out that as students of English literature, they are ready to read anything about other societies because it does not come in the way of their personal commitment to religion. It is difficult to identify how these women perceived the nature of my study, as public or private, but in most cases, they seem to be comfortable talking about these issues among friends.

Reporting gendered crime is not restricted to a single genre; in fact, all interactive shows feature such cases. Recently, it has become more common for breakfast shows to invite victims of gendered crimes (essentially acid cases and rape victims) to discuss their ordeal. Young women in the study who follow these shows shared how they feel about how everyday discussions on rape can trivialise the issue:

Bina: Our shows have a habit of making news or a programme out of gender issues, what we in fact need, are the solutions to our problems. We have emergency situation, every other day in our country (referring to rape cases), but we are hardly told anything about protecting ourselves.

Amira: Rape is a done to death theme on TV, and now we need solutions for it, we need to know what to do, whom to contact if we are in any sort of trouble.

Hira: I agree, these issues (rape) are very serious and too much reporting or discussing them on every show can even trivialise the actual nature of the issue itself.

Zainab: Our mothers have been living in the same society, and they have dealt with many issues on their own or have suffered. I don't mean that we should suffer in silence, but every individual has his or her own strengths, we just need to realize our strengths to fight for our place or rights in society, rather than just call in shows and get instant gratification. And there is one more angle to it, as female viewers, the gendered content fails to tell us about laws that protect us. It is something that has to be improved, we should bring the laws that deal with women to the fore. Is it not something that has to be the centre of this debate?

Since the genre is essentially ratings-driven, covering rape can be tricky and often seems to sensationalise crime. Bina, Amira and Zainab express worries that viewers cannot see beyond the case. Such gendered content does not meet their expectations. As educated women, they are aware of gendered realities of the society and their interest comes in knowing more about laws that protect victims. Bina, Amira, Hira and Zainab perform as cultural citizens, their eagerness to know about the laws that protect them also demonstrates how they think TV can be used effectively as a public good. Interestingly, this desire to know about women's legal rights has been consistent across the sample at Karachi University.

Amira and Hira raise concerns regarding 'too much reporting'. In Pakistan, there is a significant rise in gendered crime that is mostly unreported. Reporting across genres is a new trend for Pakistani viewers, but it is also the one that attracts viewers. From drama serials to interactive genres, all have started experimenting with gendered crimes (specifically rape) for ratings but also in part for demonstrating corporate social responsibility (c.f. Cheema, 2018). 
It is in this regard, that Amira and Hira raise their concern about desensitisation, but they are by no means showing their aversion to the representation of rape onscreen. While stressing the importance of covering gendered crime as a serious issue, Humaira (from the Psychology Department) in another group, appreciates how Hina Bayat (host of social issues-based talk show) used her show to inform viewers about their rights:

Humaira: I used to watch Geo Hina Kay Sath, we badly need programmes of that sort. It was really an initiative to make us more aware as female citizens. It not only engaged us with the women-based issues, but also informed us about the law that caters to our needs. So, there was a situation of bailout in the end, through which you could know about whom to contact and where to go in a situation like this.

Sohema: Instead of these shows, we need shows like Geo Hina Kay Sath and Aurat Kahani. (Stories of Women). We can still recall these two programmes which were committed to social awareness. These programmes were crucial in facilitating the cases enough to draw government's attention towards it or the legal process itself, but what happened thereafter is altogether another matter.

Bayat's show has been an exception being more objective about gender-based issues. The show would begin by introducing a case study and treating it as an issue of socio-political relevance. The emphasis has always been on the 'situation for bail out' and exploring avenues for psychological and legal counselling. In our conservation, Bayat shared how she wants to address men in the family and initiate discussion on gender rights in viewing contexts of the home (c.f. Cheema, 2016, 2018). I argue that hers was the only show that could be seen as similar to the concept of the public sphere in mediated contexts. Hence, Humaira aptly recalls Bayat's show as the only show that informed women about their rights and informing them of whom to contact when in trouble.

It is heartening to notice that gendered content facilitates such practices of cultural citizenship among these women. Even while acknowledging the inadequacies in breakfast shows, women respondents reflect on possibilities of tailoring televisual content to cater to their needs as citizens. In this way, content enables them to critically reflect on the status of women in society, and triggers their aspirations for taking charge of their life. The question of individual rights is also related to their socioeconomic class. At the same time, educated middle class (including both elderly and young women, c.f. Cheema, 2018) expressed distrust in the system, and that could be one of the reasons for not participating themselves directly in the shows. This kind of audience engagement and participation occurs somewhat between the civic and political, where the desire is to know about laws and to 'influence governmental action' (Dahlgren, 2009: 58).

\section{CRIME SHOWS: REPORTING RAPE IN AN UNRESPONSIVE SYSTEM}

The category of crime shows, as opposed to talk shows, is somewhat complicated. Hosts interview aggrieved parties, then get in touch with local politicians and law enforcing agencies to determine the status of the case. Initially, I did not choose crime shows because this genre is available for viewing on the news channels and I had initially selected genres on the entertainment channels. However, during the fieldwork in Karachi, my findings revealed that there is a growing enthusiasm among women respondents for these shows. In most cases, genderbased crimes (especially that of rape, incest and honour killings) are first reported on these shows and then later taken up by other interactive formats or genres for discussion. In another study, I have found that crime shows have a strong audience engagement amongst housewives in the Pakistani lower middle class. These women shared with me that they find such crime shows closer to the realities in their neighbourhood (Korangi and New Karachi). Moreover, they stressed the necessity of crime shows as their only window to the outside world - it also alerts us to their reliance on television producers for versions of reality. Most of these housewives had children attending school or working in low-paid jobs. Such shows informed them about the risks of moving about in a society apparently full of gendered crimes, and this further may reinforce segregation in society (c.f. Cheema, 2018). Interestingly, when I discussed the utility of crime shows with university students, they were more vocal about the negative consequences of watching crime. One of them reminded me of such a story which speaks volumes regarding 'the security of women' in Pakistan:

Sana: Reporting in news is altogether a different thing but bringing these issues up in talk shows or reenactment is something else, at least I disapprove of it. Do you think it would make a difference to victim's life? In fact, the trauma it leaves with the viewers is immense. After watching the case of a man who raped more than 50 female dead bodies, I and my mother remained disturbed for at least a week.

Hadia: There is so much wrong in this society, what can we do about it, perhaps just report it. We should keep our problems to ourselves and solve it internally, rather than taking it to Oscars, and letting the 
entire world know about it. We are a crises-ridden country; there is one crisis after the other, so we should fix our problems without bringing them on to the channels that are watched abroad.

Sana and Hadia exchanged thought-provoking opinions on reporting crime. Sana refers to the case of necrophilia reported in 2011 whereby a man who used to work in a graveyard raped 48 female dead bodies ${ }^{9}$ Both seem concerned about the paranoia and stress such viewing might provoke in viewers. Their responses also suggest that viewers are fully aware that reporting crime would not change gendered realities on the ground for the victims.

These crime stories seem to resonate with their life experiences, and this content has even sparked 'a sense of concern' in relation to the nation's image. ${ }^{10} \mathrm{I}$ argue that thinking about the nation's image disengages Sana and Hadia from global women issues, and instead makes them dwell on their identity as Pakistanis. As a researcher looking for counter publics, I argue that such readings are crucial in identifying intra-public divisions. For example, the counter public for gendered content identified by this study, may at times not respond to the gendered aspect of content as much as they would perhaps react to their religious obligations and duties as citizens. The content, therefore, facilitates a practice of reflecting on their intersecting identities. In this case, they chose to prioritise their identity as Pakistanis rather than as women.

Almost all the students showed some distrust in the system. While some were in favour of reporting gender based violence to the authorities, others opined that reporting has no value in a corrupt system. Students of International Relations commented on how reporting rape is a case in point:

Madiha: We feel we are more vulnerable to such crime; we felt safer in the same environment when there was limited reporting on gender-based crime. I don't think rape should neither be reported nor be spoken about, because reporting cannot do anything to facilitate the trial or bring the perpetrator before the court of law.

Zunaira: But I think it should at least be reported, for we have the right to know what is happening in our society.

Saima: These shows cannot help female victims in any way, in fact, it can tarnish the reputation of the family. In such cases, police as party to these crimes make matters worse for the victims' families, does that leave any point for discussion on TV, when we cannot seek justice through reporting.

Despite unprecedented trends in reporting, Madiha and Saima question the value of it. Their concern is not entirely unsubstantiated, in the past, there have been cases where victims' families have faced significant consequences after reporting. In 2010, Kainat Soomro, a rape victim's brother was killed after he went to the police. ${ }^{11}$ The system is not ready and equipped to protect such victims, and the role of police is frequently under question in such cases. ${ }^{12}$ While the media has started giving greater representation to sexual and gender based crimes, the judiciary and police remain largely unresponsive to such cases. Hence, one effect of this media coverage has made viewers more aware of their vulnerability in what is felt to be a corrupt system. At the same time, I argue that recent coverage of rape issues have triggered a \#metoo moment in Pakistan. Celebrities have started raising their voice for rape victims on screen and also take to the streets to protest the failing justice system. Recently, celebrities and citizens have come out with their personal stories of abuse on breakfast shows, Twitter and Facebook. The popular pressure to do something is building across media (all genres and social media) and in public domain (via protests). I see greater television coverage of gendered crime as empowering women in some ways. Recent trends of greater media reporting gives the opportunity to victims to publicly denounce their victimhood and defy traditional understanding of honour (that traditionally silences victims). I wish to argue that reporting is one step forward in Pakistani women's struggle for emancipation.

\footnotetext{
9 Tonight with Jasmeen, Samaa TV (2011) available at: https://www.youtube.com/watch?v=chxsKhXOu60 (Accessed 14 January 2018)

${ }^{10}$ Sharmeen Obaid is a filmmaker who has received an Oscar for her film on acid victims. Conservative segments in society criticise her for showcasing her film in the West.

${ }^{11}$ Kainat says her brother was killed by rape accused, (2018), Dawn [Online] Available at:

https://www.dawn.com/news/544166 (Accessed 28 January 2018)

${ }^{12}$ A very recent example is that of Zainab Amin Case, a 7-year old abducted, raped and killed by the preceptor who lived nearby home in Kasur. After five days, her body was found in a nearby garbage dump. The family tirelessly looked for the child for 5 days, even provided supporting evidence (CCTV footage) to law enforcing agencies. In a recent interview, Zainab's father claimed how his family 'seized the culprit and handed him over to the police', while police seemed uninterested in the case. In other words, victims' families have limited trust in law enforcing agencies and judiciary (c.f. Ansari, 2018).
} 


\section{CONCLUSION}

In this article, I looked at how young women respond to gendered content in interactive TV shows. The aim was to find out how women make sense of this new wave of more directly gendered content within Pakistani TV culture. This article presented findings across genres. In case of religion-based talk shows, young viewers reflect on the issue of access to the mediated public sphere in a de-personalised way (since it did not affect them so directly). Discussions on religious shows highlighted issues of living in a joint household and the tensions that inevitably evolve. In contrast, reflecting on breakfast shows, viewers expressed their reservations on covering homosexuality as a topic, here, highlighting their identity as Muslims and religion as the principal frame of reference for approaching social, gendered realities, whilst also suggesting that 'unconstrained discourse' on gender can have negative consequences on existing family structures. Crime shows made them wonder about the utility of reporting in a system that does not sufficiently protect women.

However, it is worthwhile to note that gendered content has certainly pushed the boundaries of discourse on gender and violence in Pakistani culture, and this has engaged viewers in pro-civic way. As cultural citizens, viewers returned to the content to think about their status in society and thus reflect upon their vulnerability. Viewers also want a way forward in knowing more about their rights under State Law. I read this trend as a hugely positive step in a traditional religious culture that nurtures silence on gender-based issues. If cultural citizenship is about 'the right to know and speak' (Miller, 2007: 35), then gendered content in Pakistani television has certainly pushed women to speak for their right to know about the laws that might protect them. Recently, as part of corporate social responsibility, broadcasters have started intentionally airing drama serials and breakfast shows to raise awareness on women's rights (c.f. Cheema, 2018). Non-governmental organisations that are run by feminists have also expressed interest in collaborating with broadcasters on projects of women empowerment For example, Kashf Foundation, a specialized micro-finance institution, has produced three drama serials which focus on developing awareness on women rights. Given such initiatives, I argue that current television has reduced the gap between feminists and female citizens. Given that viewers also seem to be ready to learn more about their rights, such initiatives can be empowering in the long run. Yet one needs to bear in mind that all women are not alike, their ideals for emancipation vary with religious inclination, social class, age and other intersectional factors (c.f. Shaheed, 2010). Hence, in a commercially driven media, feminist agendas on screen are subjected to the parameters of viewers choice and editorial policy (c.f. Cheema, 2018). Yet, a way forward could be finding areas of mutual concern (such as child abuse, or rape) for both Islamic and liberal feminism in Pakistan.

\section{REFERENCES}

Ahmed, L. (2011). A Quiet Revolution: The Veil's Resurgence, from the Middle East to America. New Haven, CT: Yale University Press.

Ali, B. (1986). Pakistan television Zia-Junejo Mullah show. Economic and Political Weekly, 21(50), 2171-2172.

Ang, I. (1985). Watching Dallas. London and New York: Metheun.

Ansari, A. (2018). Zainab's father claims credit for arrest of serial killer, Dawn, 26 January. Available at: https://www.dawn.com/news/1385353 (Accessed 28 January 2018).

Barlas, A. (2002). Believing Women in Islam: Unreading Patriarchal Interpretations of the Quran. Austin: University of Texas Press.

Benhabib, S. (1992). Situating the Self-Gender, Community and Postmodernism in Contemporary Ethics. Cambridge: Polity Press.

Butcher, M. (2003). Transnational Television, Cultural Identity and Change: When STAR came to India. London and New York: Sage.

Cheema, M. (2015). The Production and Reception of Gender-based Content in Pakistani TV Cultures. PhD Thesis. Sussex, UK.

Cheema, M. (2016). Producing domestic abuse in Pakistani television: between commerce, ratings and social responsibility, in H. Wheatley and R. Moseley (eds.), Television for Women: New Directions (pp. 183-202) (New York: Routledge).

Cheema, M. (2018). Women and TV Culture in Pakistan: Gender, Islam and National Identity. London and New York: I. B. Tauris (in press).

Dahlgren, P. (1995). Television and the Public Sphere, Citizenship Democracy and Media. London, New Delhi and Thousand Oaks: Sage Publications.

Dahlgren, P. (2009). Media and Political Engagement: Citizens, Communication and Democracy. Cambridge: Cambridge University Press.

Engineer, A. A. (1992). The rights of Women in Islam. New York: St. Martin's Press. 
Felski, R. (1989). Beyond Feminist Aesthetics: Feminist Literature and Social Change. Cambridge, Mass: Harvard University Press.

Fraser, N. (1990). Rethinking the public sphere: A contribution to the critique of actually existing democracy. Social Text, 25-26, 56-80. https:// doi.org/10.2307/466240

Ghamidi, J. A. (2010). Norms of gender interaction, in T. Gabriel and R. Hannan (eds.), Islam and the Veil: Theoretical and Regional Context (pp. 105-114). London and New York: Bloomsbury.

Hartley, J. (1996). Popular Reality, Journalism, Modernity, Popular Culture. London, New York: Arnold.

Hashmi, M. (2012). At the limits of discourse: political talk in drag on Late Night Show with Begum Nawazish Ali. South Asian History and Culture, 3(4), 511-531. https:/ / doi.org/10.1080/19472498.2012.720065

Hermes, J. (1998). Cultural citizenship and popular fiction in K. Brants, J. Hermes and L. van. Zoonen (eds.), The Media In Question: Popular Cultures and Public Interests (pp. 157-167). London and Thousand Oaks: Sage Publications.

Hermes, J. (2005). Re-reading Popular Culture. Oxford: Blackwell Publishing. https://doi.org/10.1002/9780470776568

Hobson, D. (1982). Crossroads: the drama of a soap opera. London: Metheun.

Hobson, D. (1994). Soap operas at work, in E. Seiter, H. Borchers, G. Kreutzner and E. M. Warth (eds.), Remote Control: Television, Audiences, and Cultural Power (pp 150-167). London: Routledge.

Isin, E. F. and Wood, P. (1999). Citizenship and Identity. London: Sage.

Kitzinger, J. (2004). Audience and Readership research in J. D. H. Downing et al. (eds.) The SAGE handbook of media studies (pp. 167-182). Thousand Oaks: Sage Publications. https://doi.org/10.4135/9781412976077.n9

Klein, B. (2013). Entertainment-education for the media-saturated: Audience perspectives on social issues in entertainment programming. European Journal of Cultural Studies, 16(1), 43-57. https:// doi.org/10.1177/1367549412457482

Kothari, S. (2005). From genre to zanaana: Urdu television drama serials and women's culture in Pakistan. Contemporary South Asia, 14(3), 289-305. https:// doi.org/10.1080/09584930500463719

Landes, J. B. (1998). The public and the private sphere: A feminist reconsideration in J. Landes (ed.), Feminism, the Public and the Private (pp. 135-163). Oxford and New York: Oxford University Press.

Livingstone, S. (2005). In defence of privacy: Mediating the public/private boundary at home, in S. Livingstone (ed.), Audiences and Publics: When Cultural Engagement Matters for the Public Sphere (pp. 163-85). Bristol: Intellect.

Lunt, P. and Pantti, M. (2009). Popular culture and the public sphere: currents of feeling and social control in talk shows and reality TV, in R. Butsch (ed.), Media and Public Spheres (pp. 162-174). Basingstoke: Palgrave Macmillan.

Lunt, P. and Stenner, P. (2005). The Jerry Springer Show as an emotional public sphere. Media, Culture and Society, 27(1), 59-81. https://doi.org/10.1177/0163443705049058

Mankekar, P. (1999). Screening Culture, Viewing Politics: an Ethnography of Television, Womanhood, and Nation in Postcolonial India. Durham and London: Duke University Press.

Maududi, A. A. (2010). Al-Hijab Purdah and the Status of Woman in Islam. Lahore: Metro Publishers.

McGuigan, J. (2005). The cultural public sphere. European Journal of Cultural Studies, 8(4), 427-443. https://doi.org/10.1177/1367549405057827

McLaughlin, L. (1993). Feminism, the public sphere, media and democracy. Media Culture and Society, 15(4), 599620. https://doi.org/10.1177/016344393015004005

McLellan, E., Macqueen, K. M. and Neidig, J. L. (2003). Beyond the Qualitative Interview: Data Preparation and Transcription. Field Methods, 15(1), 63-84. https://doi.org/10.1177/1525822X02239573

Miller, T. (2007). Cultural Citizenship: Cosmopolitanism, Consumerism, and Television in a Neoliberal Age. Philadelphia: Temple University Press.

Modleski, T. (1982). Loving with a Vengeance: Mass-Produced Fantasies for Women. New York and London: Routledge.

The Newspaper's Correspondent. (2010). Kainat says her brother was killed by rape accused, Dawn, 29 June. Available at: https:/ /www.dawn.com/news/544166 (Accessed 28 January 2018).

Naqvi, T. (2011). Private satellite media and the geo-politics of moderation in Pakistan, in S. Banaji (ed.), South Asian Media Cultures: Audiences, Representations, Contexts (pp. 100-122). London and New York: Anthem Press.

Pakulski, J. (1997). Cultural citizenship. Citizenship Studies, 1(1), 73-86. https:/ / doi.org/10.1080/13621029708420648

Press, A. L. (1991). Women Watching Television. Philadelphia: University of Pennsylvania.

Shaheed, F. (2010). Contested identities, gendered politics, gendered religion in Pakistan. Third World Quarterly, 31(6), 851-67. https://doi.org/10.1080/01436597.2010.502710

Sanli, S. (2016). Women and Cultural Citizenship in Turkey. London and New York: I. B. Tauris.

Stevenson, N. (2001). Culture and Citizenship. London and Thousand Oaks: Sage.

Suleman, S. (1990). Representation of Gender in Prime-time Television: A textual Analysis of Drama Series of Pakistani television. PhD Thesis. Wisconsin Madison. 
Talib, S and Idrees. Z. (2012) Pakistani Media and Disempowerment of Women in Carilli, T and Campbell, J. (eds.) Challenging Images of Women in the Media: Reinventing Women's Lives. Lexington Books. Kindle Edition.

Wieten, J. (1998). Reality television and social responsibility theory, in Brants, K, Hermes, J and van Zoonen, L. (eds.), The Media In Question: Popular Cultures and Public Interests (pp. 101-112). London and Thousand Oaks: Sage Publications.

Citation: Cheema, M. (2018). Talk Shows in Pakistan TV Culture: Engaging Women as Cultural Citizens. Feminist Encounters: A Journal of Critical Studies in Culture and Politics, 2(1), 08. https://doi.org/10.20897/femenc.201808

Copyright (C) 2018 by Author/s and Licensed by Lectito BV, Netherlands. This is an open access article distributed under the Creative Commons Attribution License which permits unrestricted use, distribution, and reproduction in any medium, provided the original work is properly cited. 